\title{
A simple heart valve replacement technique which improves surgical time
}

\author{
Bilgin Emrecan ${ }^{1}$, Ali Vefa Özcan¹, Ahmet Coşkun Özdemir² \\ ${ }^{1}$ Medical Faculty, Pamukkale University, Denizli, Turkey \\ ${ }^{2}$ Department of Cardiac and Vascular Surgery, Denizli Surgery Hospital, Denizli, Turkey
}

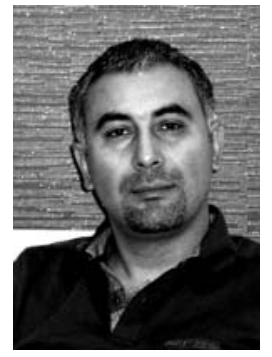

Kardiochirurgia i Torakochirurgia Polska 2013; 10 (4): 341-346

\begin{abstract}
Aim of the study: Different heart valve replacement techniques have been described in the literature. In the present study, a simple and very fast heart valve replacement technique is presented.

Material and methods: In a two-year period, 87 patients with the diagnosis of mitral valve disease, aortic valve disease or combined valve disease underwent valve replacement performed by the same surgeon. In this technique, the valve was implanted with the valve clamped to the surgical dressing without the assistant holding it. Patients with coexisting surgical pathologies were excluded from the study. A control group was created among the patients who were operated on during the same time period by different surgeons with the assistant holding the prosthesis. Control group operations were done by conventional valve holding and suturing techniques.

Results: Mean age of the patients was $61.6 \pm 3.2$ years. Mitral valve replacement (MVR) was done to 51 patients, aortic valve replacement (AVR) to 12 patients and both aortic and MVR to 24 patients. Aortic cross clamp duration was $30.7 \pm 3.3$ min for MVR, $34.8 \pm 6.2 \mathrm{~min}$ for AVR and $69.1 \pm 6.1 \mathrm{~min}$ for both valve replacements. Aortic clamping durations were significantly higher in the conventional implantation technique.

Discussion: The described technique has many advantages such as short myocardial ischemia duration, better exposure of the surgical field and facilitation of assistance.

Key words: mitral valve, aortic valve, valve surgery.
\end{abstract}

\section{Streszczenie}

Cel: W piśmiennictwie opisano wiele technik wymiany zastawek serca. W niniejszym artykule przedstawiono metodę szybką i łatwą do przeprowadzenia.

Materiat i metody: W okresie 2 lat 87 pacjentów ze stwierdzoną chorobą zastawki mitralnej, zastawki aortalnej lub obu tych zastawek przebyło operacje wymiany zastawek, które były przeprowadzane przez tego samego chirurga. W opisywanej metodzie zastawka bez uchwytu przymocowywana jest do chusty chirurgicznej po stronie chirurga przeprowadzającego operację. Pacjenci ze wspótistniejącymi patologiami chirurgicznymi zostali wyłączeni z badania. Utworzona została grupa kontrolna, składająca się z pacjentów operowanych w tym samym okresie przez różnych chirurgów. W czasie tych operacji protezy zastawek trzymane były przez asystentów. W operacjach przeprowadzonych w grupie kontrolnej użyto tradycyjnych technik szycia chirurgicznego.

Wyniki: Średni wiek pacjentów wynosił $61,1 \pm 3,2$ roku. Wymianę zastawki mitralnej przeprowadzono u 51 pacjentów, wymianę zastawki aortalnej przeprowadzono u 12 pacjentów, a u 24 pacjentów konieczna była wymiana obu tych zastawek. Czas trwania zaklemowania aorty wynosił 30,7 $\pm 3,3$ min dla wymiany zastawki mitralnej, 34,8 $\pm 6,2$ min dla wymiany zastawki aortalnej oraz 69,1 $\pm 6,1$ min dla wymiany obu zastawek. Czas trwania zaklemowania aorty był istotnie dłuższy przy zastosowaniu konwencjonalnej metody implantacji.

Dyskusja: Opisana technika zapewnia wiele korzyści, takich jak skrócenie czasu niedokrwienia mięśnia sercowego, lepszy dostęp do pola operacyjnego, jak również łatwiejsza współpraca między chirurgiem i asystentem.

Słowa kluczowe: zastawka mitralna, zastawka aortalna, operacja zastawki. 


\section{Introduction}

Since the first successful prosthetic mitral valve was implanted, there has been a great advance in the heart valve prosthesis [1]. There are different techniques for implantation of these prostheses. However, most surgeons prefer the classically suggested suturing techniques in which multiple single interrupted sutures are placed in the annulus first and then the sutures are implanted in the sewing ring [2].

In the present study, a detailed modified valve holding technique is described. The surgical outcomes are evaluated and the pitfalls of the technique are discussed in detail.

\section{Material and methods \\ Patients}

Between June 2010 and June 2012, 87 patients with the diagnosis of mitral valve disease, aortic valve disease or combined valve disease underwent valve replacement. Patients with surgically treated valvular heart disease with a valvular prosthesis were included in the study. Coexisting coronary artery disease or ascending or arcus aorta disease that necessitated simultaneous surgical correction, aortic root enlargement procedures, mitral valve or aortic valve repair procedures were excluded from the study. The data of the patients were retrospectively collected. The study mainly concerned the early in-hospital outcomes and not the mid-term or late results.

\section{Surgical technique}

The operations were done by the same surgeon under general anesthesia and intratracheal intubation. Median sternotomy was done. Pericardial stay sutures were placed. Anticoagulation was accomplished with heparin until a target activated clotting time of a minimum of 450 seconds was achieved. Standard ascending aorta and venous cannulations were done for the valve that was going to be replaced. Standard cardiopulmonary bypass techniques were used for the operations. The patients were cooled to 30-32 degrees Celsius. Antegrade isothermic hyperkalemic

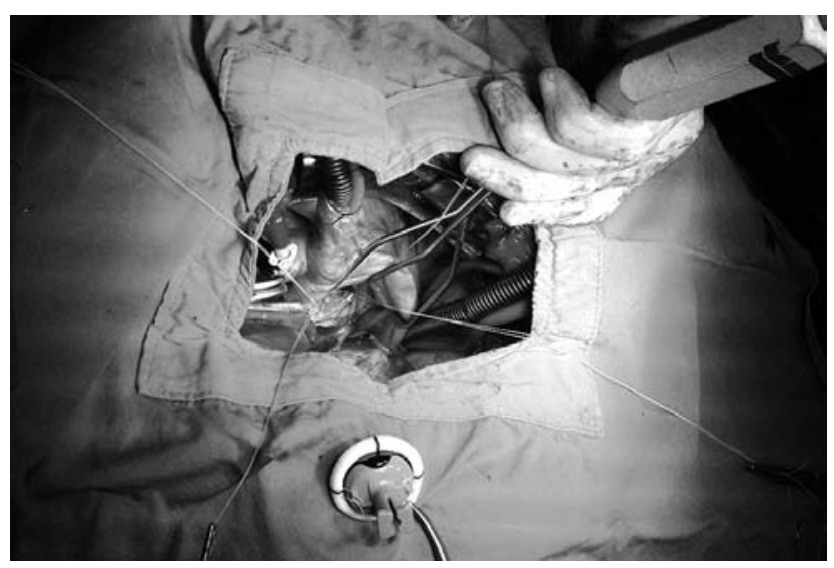

Fig. 1. The sutures applied to the annulus at 3, 6, 9 and 12 o'clock position and the valve prosthesis without its holder clamped on its sewing ring to the surgical cloth with a surgical clamp blood cardioplegia with a 4 to 1 blood to crystalloid ratio was used for myocardial protection in the cases of mitral valve surgery and additional retrograde cardioplegia for maintenance for all aortic valve procedures. A routine left atrial vent catheter was introduced for all procedures.

\section{Mitral valve replacement (MVR)}

A surgical cloth with a hole was used for surgical area isolation. The mitral valve was exposed through interatrial groove incision to the left atrium. Left atrial retractor traction was done by the first assistant. Excision of the valve was started from the center of the anterior mitral leaflet at the 12 o'clock position. A pledgetted 2-0 nonabsorbable polyfilament horizontal mattress suture was then applied, leaving the pledgettes on the left atrial side. The anterior leaflet was then excised in counter clockwise direction until the anterolateral commissure was reached. Another pledgetted 2-0 nonabsorbable polyfilament horizontal mattress suture was then applied in the 9 o'clock position. The anterior leaflet was completely excised in clockwise direction up to the posteromedial commissure and a pledgetted 2-0 nonabsorbable polyfilament horizontal mattress suture was then applied to the annulus at the 3 o'clock position. The posterior leaflet was spared in all procedures. Another pledgetted 2-0 nonabsorbable polyfilament horizontal mattress suture was then applied to the midpoint of the posterior annulus at the 6 o'clock position. The valve size was determined. The valve without its holder was gently clamped on its sewing ring to the surgical cloth with a simple surgical clamp as seen in Fig. 1. Starting from the posterior 6 o'clock suture, the suture was sewn to the valve (Fig. 2). Interrupted sutures were then passed from the annulus first and then the sewing ring subsequently in a clockwise direction (Fig. 3). After placement of the last suture of the first quadrant, the sutures were clamped and needles were cut. The valve was then rotated in a counterclockwise direction

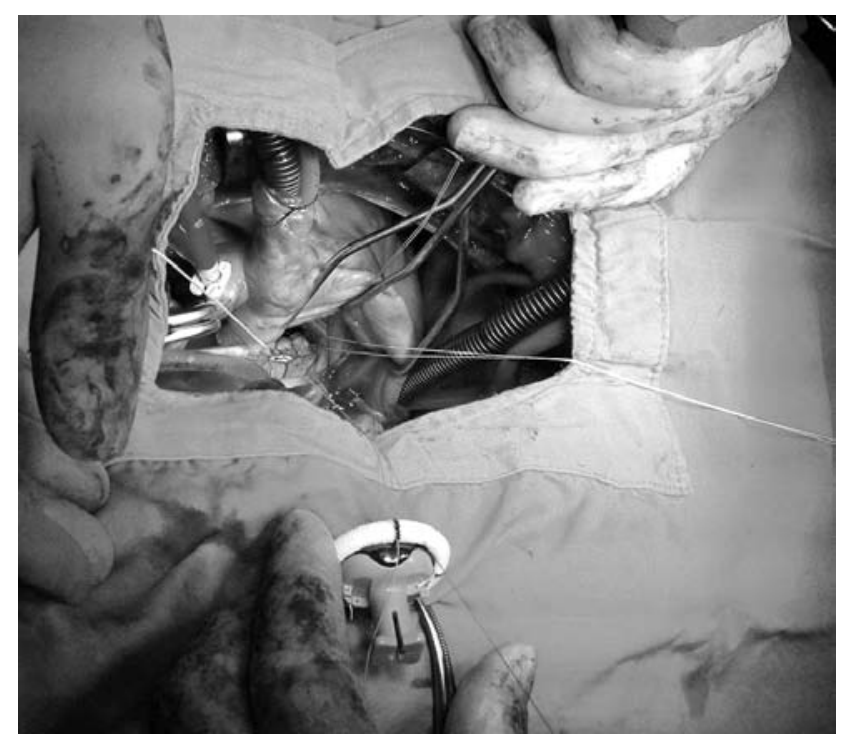

Fig. 2. 6 o'clock annular suture sewn to the sewing ring of the prosthesis 


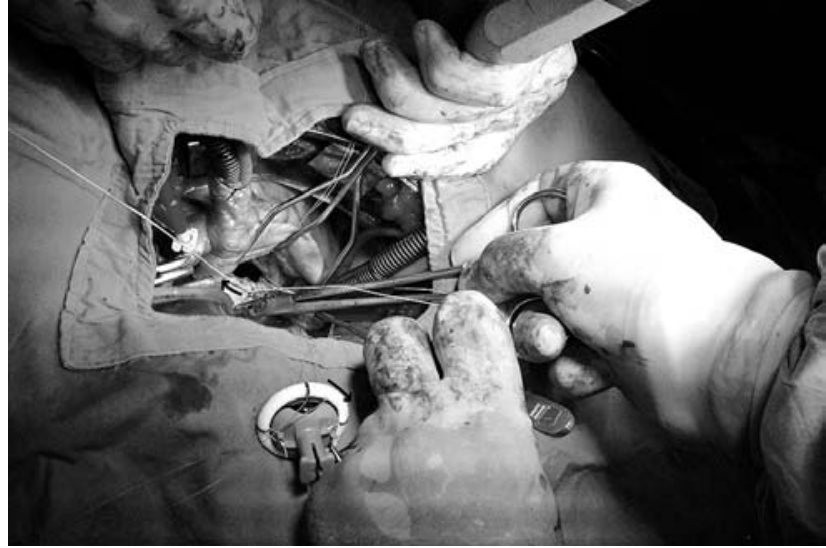

Fig. 3. Interrupted sutures passed from the annulus first and then the sewing ring subsequently in a clockwise direction. The arrows indicate the direction of the suturing from the annulus and the sewing ring

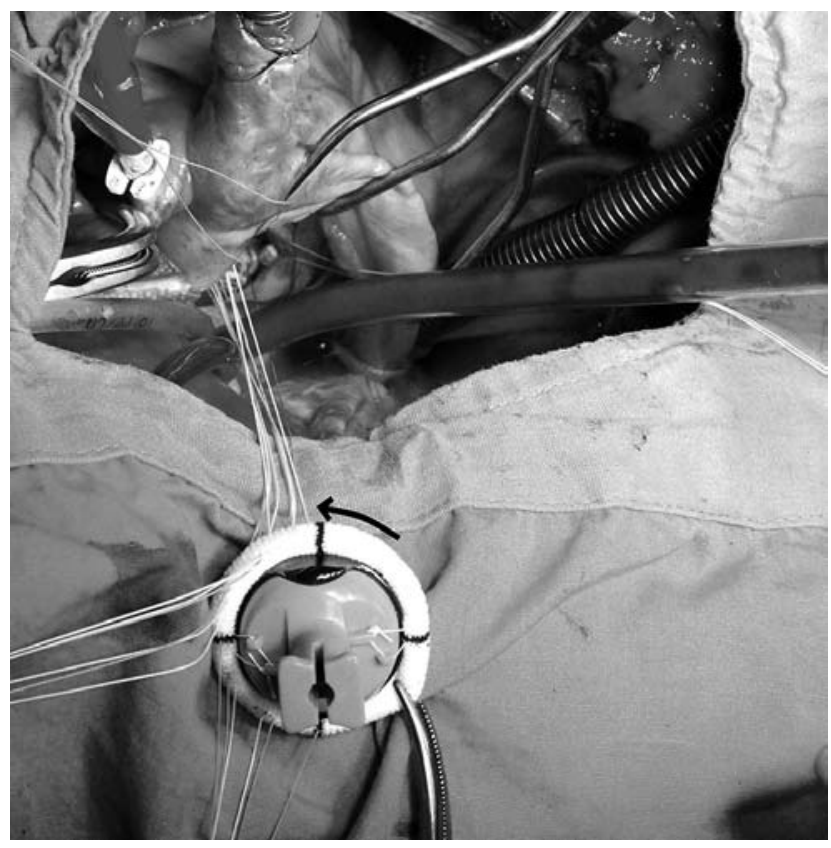

Fig. 5. Completion of the second quadrant and rotation of the prosthesis in the direction of the arrow

and was clamped to the surgical cloth again (Fig. 4). This was repeated for the first three quadrants (Fig. 5). After completion of the third quadrant, the valve was declamped and put to the left side of the surgeon without clamping it (Fig. 6). The last quadrant was then completed with the same simultaneous annular and prosthesis suturing. The ventricle was rinsed with saline and then the valve was lowered to the annulus using its holder. Starting from the posterior annular sutures, the sutures were tied in clockwise direction.

\section{Aortic valve replacement (AVR)}

Aortic valve sutures were applied in three thirds different from the mitral valve. The valve was excised starting

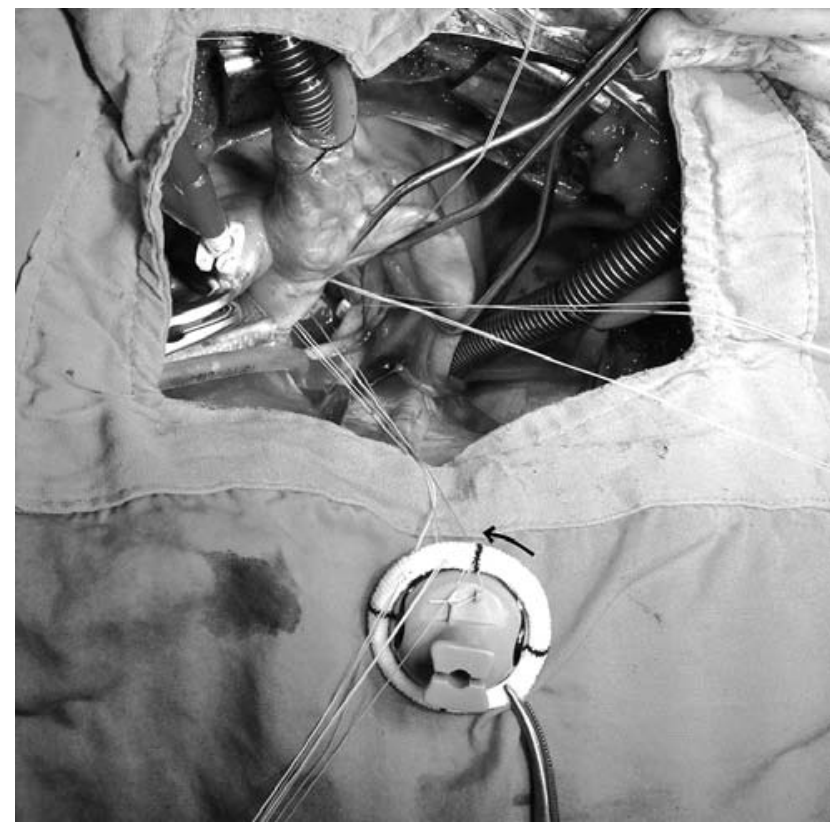

Fig. 4. The first quadrant sutures clamped, the valve prosthesis rotated in counterclockwise direction as the arrow indicates

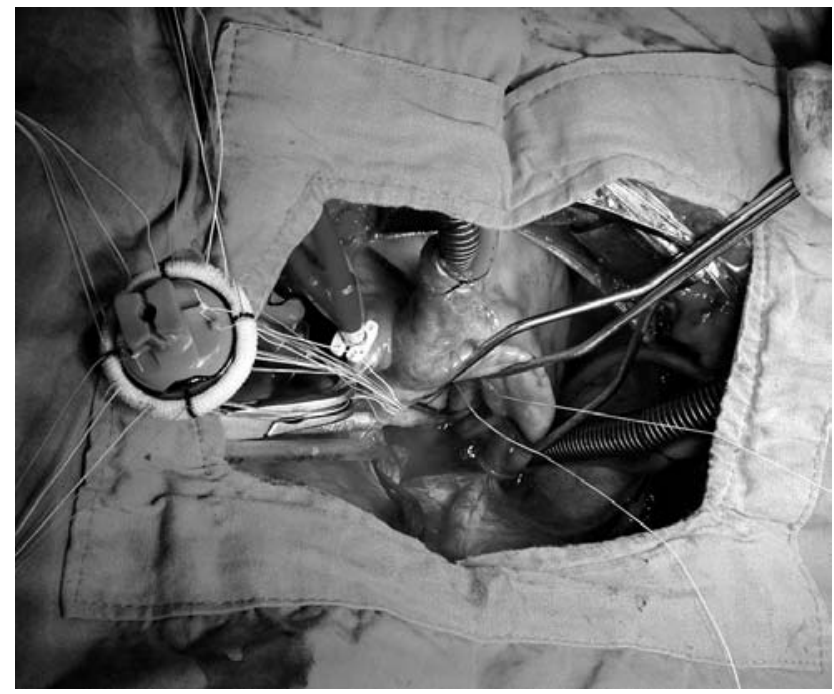

Fig. 6. Completion of the three quadrants. The valve prosthesis declamped and put to the left side of the surgeon without been clamped

from the right coronary leaflet, the left coronary leaflet and then the non-coronary leaflet. Commissural sutures were applied and the valve size was determined. The prosthetic valve was clamped as explained for MVR. This time the left coronary-non coronary commissural suture was the starting suture. The sutures were introduced in a clockwise fashion both to the annulus and the prosthesis. After completion of one third of the annulus, the valve was rotated in counterclockwise direction and clamped again to the surgical cloth. When two thirds of the sutures were finished, the prosthesis was declamped and put on the left side of the surgeon. The last noncoronary one third was 
finished and then the valve was lowered. Sutures were tied thereafter.

\section{Statistical analysis}

Statistical analysis was done with the SPSS statistical software program (SPSS Inc, Chicago, IL). For the control group, data of the same type of valvular replacement procedures during the same time period were retrospectively collected. These operations were done by other surgeons. These procedures were done using the standard classical technique in which whole sutures were applied to the annulus first, and then to the prosthesis which the assistant held. In order to make a comparison with the standard valve implantation technique 87 patients were randomly selected. The same number of each valvular replacement procedure (MVR: 51 patients, AVR: 12 patients and MVR plus AVR: 24 patients) was randomly selected among those patients who met the inclusion criteria.

The differences between the groups according to gender, smoking and diabetes were analyzed by $\chi^{2}$ test. Continuous variables were expressed as the mean $\pm 1 \mathrm{SD}$. Continuous variables were compared by the $t$-test. The $p$ values less than 0.05 were considered to be statistically significant.

\section{Results}

During the study period 87 patients were operated on for valvular heart disease. The male/female ratio was 51/36. Mean age of the patients was $61.6 \pm 13.2$ years (range 26 -82 years). Mitral valve replacement was done to 51 patients, AVR to 12 patients, and both aortic and MVR to 24 patients. Twentysix patients had tricuspid valve repair as well. One patient had revision for excess bleeding and 2 patients died due to pulmonary complications. Patients had preoperative chronic obstruc- tive pulmonary disease (10 patients), smoking (14 patients), and diabetes (4 patients).

Preoperative mean left ventricular ejection fraction was $54.0 \pm 10.8 \%$ (range $25-70 \%$ ). Mean left ventricular end diastolic diameter was $57 \pm 10 \mathrm{~mm}$ (range $40-78 \mathrm{~mm}$ ). Mean left ventricular end systolic diameter was $41 \pm 10 \mathrm{~mm}$ (range 27-68 mm). Mean bleeding amount was $490 \pm 317 \mathrm{ml}$ (range $100-1700 \mathrm{ml}$ ). Mean intensive care unit stay and postoperative hospital stay were $1.29 \pm 0.57$ days (range 1-4 days) and $6.76 \pm 1.33$ days (range 5-13 days) respectively. Mechanical valves were used for 76 patients and bioprostheses were used for 11 patients. Aortic cross-clamp time, CPB (cardiopulmonary bypass) time and size of the prosthesis are presented in Table I.

The data of the described technique were compared with randomly selected conventional operation groups according to different valves. Mitral valve replacement was compared with MVR in the control group. Aortic valve and combined two-valve operation were also compared. Each valve implantation technique group was well matched according to age, sex, diabetes and smoking $(p>0.05)$. When the surgical procedures and postoperative data were compared, there was only a significant difference according to the aortic crossclamp durations. Preoperative and postoperative data comparison showed similar insignificant differences except for aortic crossclamp durations. The comparative data are presented in Tables II and III.

\section{Discussion}

Surgical techniques on valvular replacements have been well described in the textbooks and there are few reports on this subject in the literature. Many surgeons have modified these described techniques in the textbooks according to their preferences. However, we are in the opinion that

Tab. I. Operative data of the patients in the described technique according to the valve replacement types

\begin{tabular}{lccc} 
Valve type & Cross-clamp time $(\mathrm{min})(\mathrm{min}-\mathrm{max})$ & CPB time (min) (min-max) & Prosthesis size (mm) (min-max) \\
mitral valve replacement & $30.7 \pm 3.3(24-45)$ & $49.1 \pm 4.3(38-65)$ & $27.5 \pm 1.6(25-31)$ \\
\hline aortic valve replacement & $34.8 \pm 6.2(27-52)$ & $50.5 \pm 7.6(40-70)$ & $21.6 \pm 1.4(20-25)$ \\
\hline mitral and aortic valve replacement & $69.1 \pm 6.1(58-80)$ & $93.7 \pm 8.3(70-110)$ & $\begin{array}{c}\text { Mv } 26.7 \pm 1.5(25-29) \\
\text { Ao 21.1 } \pm 1.4(18-23)\end{array}$ \\
\hline
\end{tabular}

CPB - cardiopulmonary bypass; $\mathrm{Mv}$ - mitral valve; Ao - aortic valve

Tab. II. Demographic and preoperative data comparison with control group

\begin{tabular}{|c|c|c|c|c|c|c|c|c|}
\hline & $N$ & Age (year) & F/M & DM & Smokers & LVEF (\%) & LVESD (mm) & LVEDD (mm) \\
\hline MVR & 51 & $60.0 \pm 12.7$ & $34 / 17$ & 3 & 6 & $54.0 \pm 10.9$ & $42 \pm 10$ & $58 \pm 10$ \\
\hline MVR control & 51 & $57.3 \pm 13.4$ & $36 / 15$ & 2 & 8 & $54.9 \pm 11.3$ & $39 \pm 9$ & $54 \pm 9$ \\
\hline$p$ & & 0.298 & 0.831 & 1.000 & 0.775 & 0.664 & 0.128 & 0.086 \\
\hline AVR & 12 & $66.0 \pm 9.1$ & $2 / 10$ & 1 & 2 & $60.9 \pm 5.1$ & $35 \pm 9$ & $52 \pm 9$ \\
\hline AVR control & 12 & $65.3 \pm 8.2$ & $7 / 5$ & 1 & 1 & $55.7 \pm 7.9$ & $36 \pm 5$ & $50 \pm 5$ \\
\hline$p$ & & 0.852 & 0.089 & 1.000 & 1.000 & 0.071 & 0.833 & 0.637 \\
\hline MVR + AVR & 24 & $62.8 \pm 15.4$ & $15 / 9$ & 0 & 6 & $50.7 \pm 11.4$ & $43 \pm 7$ & $57 \pm 8$ \\
\hline MVR + AVR control & 24 & $58.1 \pm 11.0$ & $13 / 11$ & 1 & 4 & $55.3 \pm 11.6$ & $39 \pm 7$ & $57 \pm 5$ \\
\hline$p$ & & 0.226 & 0.770 & 1.000 & 0.724 & 0.169 & 0.057 & 0.833 \\
\hline
\end{tabular}

LVEF - left ventricle ejection fraction; F/M - female/male; LVESD - left ventricular end systolic diameter; LVEDD - left ventricular end diastolic diameter 
Tab. III. Operative and postoperative data comparison with control group

\begin{tabular}{lccccc} 
& $N$ & $\begin{array}{c}\text { Cross-clamp time }(\min ) \\
(\min -\max )\end{array}$ & $\begin{array}{c}\text { Total amount of chest } \\
\text { tube drainage }(\mathrm{ml})\end{array}$ & $\begin{array}{c}\text { Intensive care unit stay } \\
\text { (day) }\end{array}$ & $\begin{array}{c}\text { Postoperative hospitali- } \\
\text { zation (day) }\end{array}$ \\
MVR & 51 & $30.7 \pm 3.3$ & $451 \pm 328$ & $1.21 \pm 0.57$ & $6.60 \pm 1.41$ \\
MVR control & 51 & $66.3 \pm 12.5$ & $373 \pm 227$ & $1.21 \pm 0.46$ & $6.96 \pm 1.92$ \\
$p$ & & $<0.001$ & 0.165 & 1.000 & 0.295 \\
\hline AVR & 12 & $34.8 \pm 6.2$ & $452 \pm 386$ & $1.25 \pm 0.45$ & $6.83 \pm 1.37$ \\
AVR control & 12 & $65.9 \pm 9.5$ & $350 \pm 213$ & $1.25 \pm 0.45$ & $6.75 \pm 0.96$ \\
$p$ & & $<0.001$ & 0.432 & 1.000 & 0.863 \\
\hline MVR + AVR & 24 & $69.2 \pm 6.1$ & $591 \pm 234$ & $1.45 \pm 0.59$ & $7.04 \pm 1.12$ \\
MVR + AVR control & 24 & $106.6 \pm 19.4$ & $490 \pm 315$ & $1.21 \pm 0.59$ & $6.58 \pm 1.24$ \\
$p$ & & $<0.001$ & 0.215 & 0.148 & 0.188 \\
\hline
\end{tabular}

there are still difficulties that surgeons meet during these procedures. Classically, in both mitral and aortic valve replacements, the sutures stay in the surgeon's view, whereas the sutures stay away from the surgeon's view in the presented technique because when working on the posterior annulus, the valve prosthesis stays on the surgeon's side. When working on the anterior annulus, the sutures again stay away from the surgical view. Traction of the previous suture lowers especially the anterior annulus into the surgical view in mitral position. This facilitates suture implantation in the annulus. Another and maybe the most important advantage of the presented technique is that the first assistant does not have to hold the prosthesis or the sutures. Therefore he may help the first surgeon with the other hand. There are sternal retractors with some attachments on them to place a mitral retractor. Nevertheless, retraction by an assistant is sometimes necessary when the mitral position is difficult for suture implantation.

In the classical techniques, when using the interrupted suture technique, all of the annular sutures are placed first and these sutures are placed in the sewing ring thereafter. This technique has some disadvantages. First of all, many sutures when applied may be entangled and separation of these sutures may sometimes be difficult. This will prolong the operation time as well. A purpose-made retaining device for suture holding has been presented in order not to mix these sutures. Another solution is to use different colored sutures [3]. However, even these solutions are not satisfactory. The currently presented technique solves the problem as the sutures are placed in the annulus and then subsequently in the sewing ring. This avoids mixing as well as accidental suture crossing. Another difficulty is the needles, which sometimes complicate this problem, but this is also solved in the presented technique. Removing needles as soon as possible makes threads easy to handle and decreases accidental puncture of surgeons' gloves.

The most challenging difficulty of the presented technique is that the surgeon should guess the distance between the quadrants and calculate how many sutures to place on the annulus in that quadrant. This is important to properly locate sutures in the sewing ring. Mostly 12-14 pledgetted sutures in mitral and 9-12 in AVR are enough in most of the operations, so most of the time this has not been a challenge for us.

Clamping the sewing ring to the cloth may be thought to harm the sewing ring but this has never been seen due to the fact that clamping the sewing ring with a toothless clamp is not traumatic. Clipping the prosthesis to the surgical towel will also avoid the prosthesis from the patient's skin organisms. The bioprosthesis does not complicate the described technique as well.

In the continuous suture technique, the prosthesis is tightly approximated to the annulus and the slippage of the suture loops makes the tension equalized with heart motion. This technique also speeds up the procedure [4]. A running suture for implantation of mitral valves makes a very clean suture line with minimal knots, although it has the risk of valve dehiscence if an infection occurs [1]. Continuous running suture technique is found to be advantageous when speed is taken into account [5]. A study comparing the continuous suture technique with the interrupted suture technique has shown an increase in the risk of paraprosthetic regurgitation in both mitral and aortic positions. Need for reoperation has been significantly higher in the continuous suture technique after mechanical AVR [6].

In a study comparing a newly designed sutureless valve with conventional AVR, the mean aortic cross-clamp and CPB times have been found as $34 \pm 15 \mathrm{~min}$ and $59 \pm 21 \mathrm{~min}$, respectively. These short durations of the aortic crossclamp and CPB times were reported to reduce mortality and morbidity [7]. When compared with interrupted suture technique, continuous suture technique has been found to have shorter aortic cross clamp times ( $85.9 \pm 32.9$ vs. 46.3 \pm 20.4 ) [8]. Our study demonstrated even shorter durations. In a study comparing port access mitral valve procedures with standard mitral valve techniques, the crossclamp time was found longer with port access. In this study standard MVR cross clamp time was found as $64.6 \mathrm{~min}$ [9]. Another study demonstrated a cross clamp time of $43 \pm 15$ min for conventional MVR technique [10]. In the presented technique, the cross clamp time was $30.7 \pm 3.3 \mathrm{~min}$ for MVR. The aortic cross-clamp times were nearly the same as the sutureless valve implantation durations. In the present study, we did not focus on the surgical outcomes but 
the operational data. The crossclamp times were excellent and in hospital outcomes were acceptable.

The mean aortic valve size in the present study is relatively small, with a mean of 21.6. This may cause a patientprosthesis mismatch. We do not preoperatively plan the size of the prosthesis to be implanted. But in practice we decide to enlarge a root when the valve size is below 19 or when a patient has a relatively large body surface area. On the other hand, enlarged aortic roots were excluded from the study, which in fact might lead to wrong analysis of the replacement durations. In a study, supra-annular mattress sutures were offered to implant a bigger prosthesis. In addition, in that study below the valve size of $25 \mathrm{~mm}$, left ventricular mass index only decreased in stentless biological aortic valves when compared to mechanical or stented biological aortic valves. The authors also mentioned that early left ventricular mass regression had not been due to residual gradient but due to afterload reduction [11]. Although we also used supra-annular sutures, we think that prosthesis size may be increased to some extent with pledgettes below the annulus or with continuous sutures. However, sub-annular pledgettes may disappear if the suture is broken during tying. Disadvantages of continuous sutures have been discussed previously.

A major limitation of the study is its retrospective design and comparison of two techniques done by different surgeons. The small population, especially in the AVR group, may make it difficult to reach conclusions. Another limitation may be the lack of late results of the procedures, which in fact may be a further study.

To conclude, the presented technique provides some practical solutions to the above-mentioned pitfalls of valve replacement.

We would like to thank Prof. Dr. Ali Gürbüz for his great efforts in teaching the presented technique.

\section{References}

1. Gudbjartsson T, Absi T, Aranki S. Mitral valve replacement. In: Cardiac surgery in the adult. Cohn LH (ed.). The McGraw-Hill Companies, New York 2008; 1031-1068.

2. Emery RW, Emery AM, Knutsen A, Raikar GV. Aortic valve replacement with a mechanical cardiac valve prosthesis. In: Cardiac surgery in the adult. Cohn LH (ed.). The McGraw-Hill Companies, New York 2008; 841-856.

3. Shemin RJ. Technique for aortic valve replacement with bioprosthetic and prosthetic valves. Operative Techniques in Thoracic and Cardiovascular Surgery 2000; 5: 251-258.

4. Kouchoukus NT, Blackstone EH, Doty DB, Hanley FL, Karp RB. Aortic valve disease. In Kirklin/Barrat-Boyes Cardiac surgery. Churchill Livingstone, Philadelphia 2003; 554-656.

5. Wheatley D, Will M. Mitral valve replacement with mechanical or bioprosthetic valve. Multimed Man Cardiothorac Surg 2005; 2005 (425): mmcts.2004.001024.

6. Nair SK, Bhatnagar G, Valencia O, Chandrasekaran V. Effect of valve suture technique on incidence of paraprosthetic regurgitation and 10-year survival. Ann Thorac Surg 2010; 89: 1171-1179.

7. Shrestha M, Folliguet T, Meuris B, Dibie A, Bara C, Herregods MC, Khaladj N, Hagl C, Flameng W, Laborde F, Haverich A. Sutureless Perceval S aortic valve replacement: a multicenter, prospective pilot trial. J Heart Valve Dis 2009; 18: 698-702.

8. Watanabe G, Ushijima T, Tomita S, Yamaguchi S, Koshida Y, lino K. Revival of continuous suture technique in aortic valve replacement in patient with aortic valve stenosis: a novel modified technique. Innovations (Phila) 2011; 6: 311-315.

9. Ryan WH, Brinkman WT, Dewey TM, Mack MJ, Prince SL, Herbert MA. Mitral valve surgery: comparison of outcomes in matched sternotomy and port access groups. J Heart Valve Dis 2010; 19: 51-58.

10. Walther T, Walther C, Falk V, Diegeler A, Krakor R, Schneider J, Autschbach R, Mohr FW. Early clinical results after stentless mitral valve implantation and comparison with conventional valve repair or replacement. Circulation 1999; 100 (19 Suppl): ॥18-॥83.

11. Cakici M, Durdu S, İnan B, Yazicioglu L, Sirlak M, Eryilmaz S, Uçanok K, Uysalel A, Özyurda Ü, Akar AR. Changes in left ventricular function and geometry after aortic valve replacement in patients with severe aortic stenosis. Türk Göğüs Kalp Damar Cerrahisi Dergisi 2013; 21: 284-293. 